\title{
Correction to: Escherichia coli bacteriuria in pregnant women in Ghana: antibiotic resistance patterns and virulence factors
}

\author{
Akua Obeng Forson*, Wilson Bright Tsidi, David Nana-Adjei, Marjorie Ntiwaa Quarchie \\ and Noah Obeng-Nkrumah
}

\section{Correction to: BMC Res Notes (2018) 11:901}

https://doi.org/10.1186/s13104-018-3989-y

Following publication of the original article [1], the authors reported that one of the authors' names was spelled incorrectly. In this Correction the incorrect and correct author name are shown. The original publication of this article has been corrected.

Originally the author name was published as:

- Noah Obeng-Nkuramah.

The correct author name is:

- Noah Obeng-Nkrumah.

\section{Publisher's Note}

Springer Nature remains neutral with regard to jurisdictional claims in published maps and institutional affiliations.

Received: 18 December 2018 Accepted: 7 January 2019

Published online: 16 January 2019

\section{Reference}

1. Forson AO, Tsidi WB, Nana-Adjei D, Quarchie MN, Obeng-Nkrumah N, et al. Escherichia coli bacteriuria in pregnant women in Ghana: antibiotic resistance patterns and virulence factors. BMC Res Notes. 2018;11:901. https://doi.org/10.1186/s13104-018-3989-y. 